\title{
Linguistic Aspects Revealing Politeness in EFL Community of Practice
}

\author{
Nunung Nurjati \\ Universitas PGRI Adi Buana Surabaya \\ Surabaya, Indonesia \\ nunung_nurjati@unipasby.ac.id
}

\author{
Fabiola D. Kurnia \\ Universitas Negeri Surabaya \\ Surabaya, Indonesia \\ fabiola@unesa.ac.id
}

\author{
Suharsono \\ Universitas Negeri Surabaya \\ Surabaya, Indonesia \\ suharsono@unesa.ac.id
}

\begin{abstract}
Politeness has long been debatable among academics in various fields, particularly in linguistic, behavior, and cultural studies. What make politeness disputable is whether the concept of politeness itself can be accepted by all parties and what should be analyzed as an aspect of politeness. It is as well as to which still a debate is the aspects that are considered as indicators of politeness. Therefore, this paper is aimed to elicit the aspects revealing politeness in English as Foreign Language (EFL) community of practice settings. Through ethnoparticipation in the fieldwork by disguising as participant and recording on the subjects under the study, the collected data are then analyzed using the discursive approach. As the findings of the study, linguistic aspects are interpreted by relational work approach to reveal politeness in the fieldwork.
\end{abstract}

Keywords-politeness; linguistic aspects; EFL; community of practice.

\section{INTRODUCTION}

The critique by Eelen [1] on the influential politeness theory of 'facework' by Brown and Levinson encourages the growth of views that is different from what has been followed so far. Undeniably, this change can be identified from the emergence of the growing number of studies which employ a new form within politeness research as the so-called 'postmodern' or 'discursive' approach [2];[3];[4];[5];[6]. This new view on politeness theory in fact does not reject the traditional Brown and Levinson's framework rather this postmodern approach would correct its limitation and improve the value in it [1];[3];[4];[6];[7].

While politeness as concept is still debatable among scientist, politeness as practice has been formed and become the characteristic of a society. Politeness is embedded in the interaction among member of its community of practice as a part of society. There are two factors that influence the interactions which are said to form such politeness. The first one is the influence of local culture. It is stated that the local belief system is very important in delivering the meaning of utterances which are associated with the performance of politeness implemented in communication in certain areas [8]. Local feature which is embodied in culture has many different dimensions. It includes ideas, customs, skills, arts and tools that characterize a group of people in a given period of time; it is also the beliefs, values, and material objects that create our way of life. The second one is the differences in understanding in using the phrases as an expression of an interaction. The differences in the concept may result in differences in the use of sentence structure and the choice of words in sentences or communication style [9];[10];[11]. The style includes choice of vocabulary and syntax, prosody and paralinguistic behavior (e.g. intonation, stress, tone of voice, pitch, pacing, pausing and loudness) as well as non-verbal behavior (e.g. gestures, spatial relations and touch). In later practice, these styles refer to the strategy of direct-indirectness of cross-cultural communication as for example of German speakers display greater directness while Chinese speakers can be very indirect in communication [10]; [11].

By exploring the problems mentioned earlier then come into account that politeness which is utilized by community of practice in particular area needs to be described. Further, the goal of acquiring English speaking skills is that of successful communication. In the context of communication in EFL speakers in a community of practice, the existence of politeness may be arisen both in speech and behavior. Since politeness arises in natural interaction, politeness in EFL speakers in that community of practice should be identified. In line with that, this study is intended to answer the research question:

1. What linguistic aspects of politeness are revealed in EFL community of practice?

2. How are those linguistic aspects of politeness revealed in EFL community practice?

\section{A. Current Approach in Politeness Research}

Brown and Levinson [9] theory has offered scholars massive amount of research in politeness. Scholars believe that Brown and Levinson's model has contributed a lot in the study of politeness discourse although there are many criticisms that have been made by some researchers due to its lack of clarity concerning the definition of politeness and related concepts of across studies and within the same studies [12]. Moreover, Eelen [1] provides a critique of Brown and Levinson's theory about the application of universal theory of politeness that can 
be applied by anyone in this part of the world. Eelen [1] argues that Brown and Levinson's theory of politeness cannot be said universally because their theory examines only 3 languages in the world. Furthermore, the Brown and Levinson's theory is said to be ethnocentric because it is derived directly from the high value which is based on individualism in the Western cultures and the fact that their distinction between the negative and positive politeness is doubtful [11];[12].

The critics, such as in Brown and Levinson [9] tried to prove the postulation that politeness has similar view for all groups within society. Those who oppose Brown and Levinson theory, then, introduce discursive approach. Discursive approach allows interpretation to consider behavior to be merely appropriate and neither polite nor impolite, while relational work, the work individual invests in negotiating relationship with others which include merely appropriate behavior or polite as well as impolite, is a useful concept to help investigate the discursive struggle over politeness [4]. Since Brown and Levinson only describing mitigation of FTA, so this does not account to politeness which is includes in area of appropriateness, unmarked and politics. In addition, it does not relate to impoliteness which comprises aggressiveness, rude, and abusive. In other word, Brown and Levinson theory of 'facework' depicts only appropriate and polite behavior with a focus of FTA mitigation. It does not describe rude, impolite and inappropriate behavior.

The elaboration of new approach in analyzing politeness above, illustrates if politeness can be analyzed not only through words, phrases or sentences, but can use the discursive approach. This discursive point of view is different from the perspective of politeness analysis introduced by Brown and Levinson through the theories of 'facework' which explains politeness through the study of words, phrases in the use of language by interactors. In fact, in interaction, to understand meaning, it takes not only words or sentences that can shape understanding, but also the context of the conversation that takes place. This is what underlies the researcher choose discursive approach in analyzing politeness considering the object of this study is EFL speakers who naturally interact in the environment of the community of practice under different contexts.

\section{B. Relational Work Approach}

Relational work is defined as "the process of defining relationships in interaction." It refers to "the work of individuals invests in negotiating relationship with others" [4]. The term has a meaning that people, as part of society, needs others to realize life and pursue the goal of life. They must be aware of their interdependency on others. It is based on the idea that any communicative act has both an informational as well as an interpersonal aspect [12];[13]. It means, communicative acts always represent some form of relational work. Taking this approach means that we are not restricted to studying merely the polite variant of the interpersonal aspect of a communication, as Brown and Levinson [9] have predominantly done, but can equally focus on impolite, or rude aspects of social behavior. Relational work, in other words, includes the entire spectrum of the interpersonal side of social practice.
Perceptions of the perpetrator of the interaction in general are classified into four continuums. To be clearer in understanding the four continuums, Locher and Watts [4] resume as follows:

- Continuum 1 (negatively marked/impolite/non-politic or inappropriate). If behaviors that are deemed to violate social norms and are marked negatively will be called impolite by the community of practice.

- Continuum 2 (unmarked/non-politic/politic or appropriate). It is the norm that prevails in society so that people do not respond or give comment on linguistic interactions that occur in the community of practice based

- Continuum 3 (positively marked/polite/ politicappropriate). If an interaction produces a comment that is considered a polite by the interactants in the community of practice.

- Continuum 4 (negatively marked/over-polite/ nonpolitic or inappropriate). If behaviors that are deemed to violate social norms and are marked negatively will be called over-polite by the community of practice.

It is important to emphasize that the term relational work does not only refer to polite linguistic behavior, but is intended to cover the entire spectrum of interpersonal linguistic behavior. Polite, refined, and polished language might create a person's identity construction, but so does rude, impolite, and aggressive language [4];[14];[15];[16]. Determined by the kind of verbal social behavior in which individuals engage, they will adapt their relational work to what they have constructed in prior interaction as appropriate behavior. What is perceived to be (im) polite will finally count on the interactants' assessments of social norms of appropriateness that have been previously acquired in the speech events [4];[7];[14];[15];[16]. Therefore, impoliteness related phenomena has also been accommodated in relational work [15];[17]. This, however, in compliance with Brown and Levinson's 'facework' which describe only appropriate and polite behavior with a focus on face-threat mitigation without mentioning rude, impolite and inappropriate behavior.

\section{Linguistic Aspects Indicating Politeness in EFL Community of Practice}

To identify politeness among the practice in certain community needs some indicators as guidance to specify to which the certain practice of language can be determined that politeness' occurrence is assumed to exist. This, therefore to be identified from linguistic aspects in the interactions engaged among members of community of practice. Those aspects are the notification that politeness employed by its interactants in the interactions. Those aspects among others are: 1 ) addressing terms, 2) rising intonation, 3) codeswitching and codemixing, 4) using agreement, 5) using joke, 6) using taskoriented/instruction, 7) using indirectness, 8) using metaphor, 9) using non-serious utterance, 10) using hyperbole, and 11) using mockery. 


\section{METHODS}

The research was conducted on ethno-participation which place the researcher undercover as active participant in EFL community of practice from July 2017 to January 2018 with on-and-off intermittently. From hundreds of English courses in the fieldwork, object of the study had to be chosen with careful considerations: 1) having established or continued for a long time, 2) most selected online, and 3) most preferred by course participants. The considerations are set by the researcher after conducting several field surveys; by searching for information online and asking the participants of the course randomly at various courses. From those set of requirements then five English courses were selected.

The data were in the form of natural occurring utterances in a longer stretch of talk or discourse which instances of politeness are used. Source of data were the member of EFL community of practice which consists of teachers, tutors, course's participants, camp's members, and food-sellers. To collect data, the researcher used recording technique by utilizing sensitive-mini recorder which was slipped undetectably by the source of data. The raw collected data were listened and then selected to be transcribed which display the marker of linguistic aspects as instances of politeness. Data were then analyzed in these steps: organizing data, separating data into organized units, synthesizing data, searching for patterns, discovering which linguistic aspects will be analyzed and then deciding what to report as findings.

\section{RESULTS AND DISCUSSION}

\section{A. Addressing terms}

What is found in EFL community of practice that the usage of title mister is used for greeting to any male no matter who they are from power, distance, and rank difference. It is used by the students to address their teacher and tutor as well as used by the teacher and the tutor to address their student in classrooms and camps. However, in everyday use in mother tongue (L1) in classrooms, teachers address their student mostly used by name without pak. This usage in mother tongue is a conventional pattern of addressing term since it reflects norms in given classroom's situation. While for female, it is a common address miss for female teachers and ma'am or mom to adult or older woman.

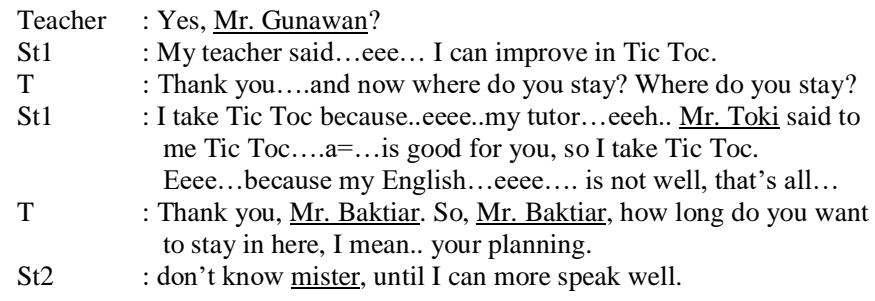

It is found from the dialogue that addressing norm in classroom is in contrast with standard in native countries which refers to the use of Title+Last+Name (TLN) [18]. Teacher addresses the student by employing Title+First+Name (TFN) in Mr. Gunawan and Mr. Baktiar which is uncommon

in native countries. The teacher addresses male student using TFN instead of directly calling only by their name. By addressing mister before the student's name, the teacher actually intends to give respect to the students. In a language with a system of honorific the normative use of honorific can serve as a form of positive politeness [19]. Positive response is delivered by the hearer in the interaction as the evaluation when the speaker uses addressing term to the addressee. Therefore, addressing terms is positively/polite/politicappropriate marked. It is proven that such address to the speakers of community practice is prevailing norm to follow.

\section{B. Rising intonation}

From the interaction, it is marked that someone rising intonation is intended to let the hearer understand what they mean in the utterance. By raising the intonation, the speaker (teacher) wants the hearer (student) to respond appropriately. The response comes from the last sentence of the teacher by raising the intonation as an affirmation of the intention which not previously captured by the student as the hearer. In most situation utterance with raising intonation other than as a question marker, it is as well as an indication of affirmation of the spoken sentence. The manner of pronunciation by raising the intonation can result in the listener which can be regarded as threatening the face of the listener [18]. Raising intonation by the speaker is unmarked by the hearer because it is not an effort of threatening the hearer's face. Even, it is not a way of yelling at the hearer.

$\mathrm{T}$

St1

$\mathrm{T}$

St1

The judgment of its addressee to the speaker's utterance neither is unmarked as having no tendency nor threatens the listener's face since the response from the hearer is not positive or negative. Therefore, the interaction is confirmed as non-politic/appropriate relational work. It is appropriate to both the speaker and the hearer since the confirmation of negotiation signals that there is a norm as in classroom's instructional activities which are equally compiled by both interactional parties. A prevailing norm, in which the teacher is allowed to raise her voice, is as long as the teacher aims to succeed the learning that is being carried out by her.

\section{Codeswitching and codemixing}

It is found that EFL speakers in community of practice mix and switch bilingual language in their interactions in any places such as in classrooms, camps or other place where English is spoken as means of communication. In classrooms, the use of code mixing and code switching is influenced by the level of proficiency and course type. In the more advanced level of English proficiency, the use of code mixing and code switching is more limited. However, in basic and intermediate proficiency classrooms, the use of code switching and code mixing still dominate the conversations between teachers and students. 
T Alright nama selalu susah dilakukan. What number? St : Number six ((THE STUDENTS ARE MUMBLING))

$\mathrm{T} \quad$ : Excuse me $\uparrow . . .$. Lucky, kamu hari ini tidak volunteer, to? St : No, ma'am

T : Endak??

The constant use of codeswitching and codemixing may cause of no offence to both the hearer and the speaker. Thus, it results in neutral in response for the hearer.

\section{Using agreement}

Agreement is shown on the use of notification 'agree' as the response on the utterance. Another marker of agreement is saying 'yes' or 'yeah' as the response. Another response by the hearer can be expressed in non-verbal linguistic features such smiling, nodding or producing audible sound such as 'ehm' in the response to the speaker's statement. The context is believed as the factor intensifies the difference.

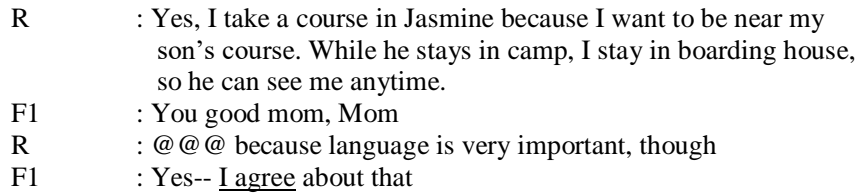

Showing agreement as positive response to the speaker implies that the speaker appreciates the hearer through her opinion. This allows the speaker seems to be appropriately acceptable about the assessment. Then, it is judged that such utterances are enhancing positive face by gaining the hearer's positive attributes from its counter interactant.

\section{E. Using joke}

Teacher and student relationships are always formal and instructional. This situation creates awkwardness that everyone is reluctant to interact. To tease the situation, teacher initiates in using joke to mitigate pressure which grows between them in the interaction.

$\mathrm{T}$

: The first presenter today! The first presenter! Siapa yang di tunjuk hari ini? Uh... kemarin terakhir.

Mala. Mala.. choose your friend. Mala, it's a boy today.

Mala : Number 3

$\mathrm{T} \quad$ : number 3 is John, where are you John? ......(7.0) John??

Does not come yet? Apa tiba-tiba tidak mengaku?

Sts : @@@

John : absent!

((LAUGHING ALOUD))

((MEANING: PRESENCE))

This is interesting that the use of joke, apparently is effective in shorten the distance between the interlocutors. The situation itself is face-threatening that the teacher produces provocative utterance 'Does not come yet?' which is like an accusation that the intended student is absence. John may think if he shows his presence in class, he will get the turn to present a material in front of the classroom. Then, the laughter breaks from his classmates which indicate that his teacher's utterance is a joke. John consciously saying his presence is as a positive response to the teacher's joke. His teacher's utterance is a face-enhancing to John who feels closer by understanding the intent of his teacher. The way the teacher displayed in the interaction can be said that the strategy of positive politeness is being applied by the speaker in an attempt to make the hearer feel closeness.

\section{F. Using task-oriented/instruction}

In an instructional conversation, the use of imperative and interrogative speech is apparent in teachers' side, particularly the interrogative one. The teacher uses interrogative to confirm on things, to get the answers from the students and to get the things done by the students. The generic form of interrogative is by using to be, the question words or modal auxiliaries in the beginning of the sentence.

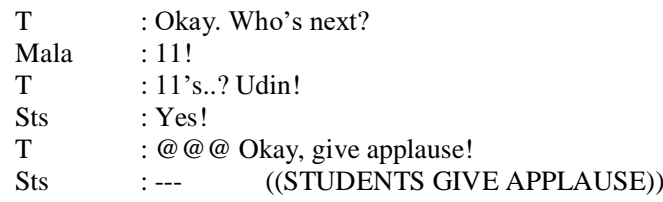

Teacher fulfils the task by using interrogative speech 'Who's next?' to the students urging who the next turn is for a class presentation. In return, one of the student responds by mentioning a number on list of the student. Task-oriented is delivered to get response from the students. In classroom situation it is a norm that nobody would feel offense by responding question and do what the teacher ask for. This kind of interaction, therefore, is considered neutral or no facethreatening act to both the speaker and the hearer.

\section{G. Using indirectness}

The situation faced by the teacher on entering the classroom, when mostly students are engrossed with their own gadgets, it seems that the presence of the teacher is not apprehended by the students. To distract from their gadget and to awaken upon the presence of their teacher, the teacher uses metaphorical utterance 'I will bring in a witch to dispel the evil of blue Monday' to her classroom's students. The teacher seemingly avoids of using a more direct sentence like 'Save your gadget and start class immediately'

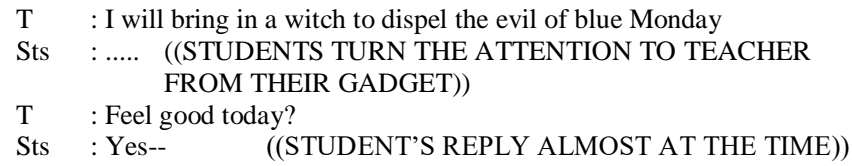

The indirect expression that the teacher uttered has forced the students effectively distracting from their gadget back into the class' attention again. On the other hand, the use of direct sentence by the teacher may have an unexpected effect like negative response or indifference. No argument appears from the students instead they put away their gadget and put back the attention to the teacher and classroom. As a response from getting her students' attention back, the teacher uses 'Feel good today?'

\section{H. Using metaphor}

Metaphor expression can be used in utterance that aims as a vague request to the listener. The impact caused by the use of metaphor is the listener as if not asked to do something. 
Somehow, the sentence the teacher asks is to instruct the student to do something.

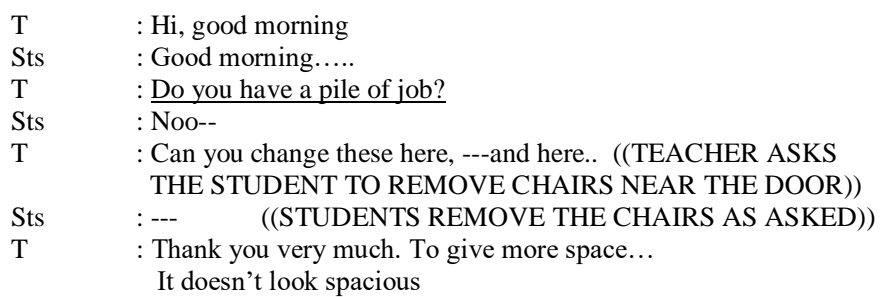

The students' response toward the use of metaphor by the teacher shows positively marked/polite/appropriate behaviors which results in reducing face-threat toward the students as the hearers. It is associated with negative politeness (the kind of politeness that tries to avoid offence). Polite utterance is a speaker's intended, marked and appropriate which demonstrate face concern and respect addressee and the speaker's need for independence [6]. Since the hearer gives positive responses (positively marked) in this case the interaction of both is considered polite then the interaction between speaker and hearer is considered appropriate or politic or appropriate. Response positively occurs because each interlocutor is considered to be mutually face saving (face-enhancing) in interaction.

\section{Using non-serious utterance}

Non-serious utterances are shown in line 1-2 by the teacher by uttering 'I'm back@@@...and, I'm alive again' It is true that she has been off for only one meeting by saying that she is back to the classroom, this means that her saying should not be taken seriously as if she had been away for long time. Her saying is followed by laughter which implies that she does not mean with her utterance. In certain occasion, non-serious utterance is used when the tense grows between interlocutors. It seemingly that the teacher thinks that she has left her classroom. On the contrary, the response from the students is not as assumed by the teacher. The students respond in silence.

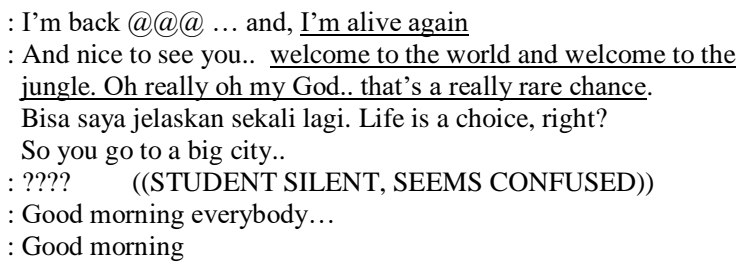

This situation illustrates the ineffectiveness of the communication relation that occurred. On one hand, feeling guilty of the teacher for being away from the classroom creates distance to her students. To shorten the distance, she expresses it in an indirect way of using non-serious utterance to be considered polite. On the other hand, the student does not understand what the teacher is saying. In fact, the teacher's sentences are considered imposing. The silence of the students as realization of their judgment of the teacher's utterance shows if they keep their distance and wait for the teacher to

say next. Clearly, there is a norm that is always followed by the students in the classroom before starting a lesson, the teacher should designate with a greeting as opening remark, regardless of anything covers the mind of the teacher or previous event experienced by the teacher before entering the classroom. Expressing anything although it is meant to be polite whenever it is violating norm will cause negative assessment on the side of the hearer.

\section{J. Using hyperbole}

It is found that the speaker using hyperbolic utterance is the way of expressing which involves exaggerating literal description of particular things. question time. Kok saya yang tanya terus...

Sts $\quad:$......... (10.0) ((SILENT, NO QUESTION))

$\mathrm{T} \quad$ : Would you share your question, ladies and gentlemen?

The presenter needs your questions.

Sts $\quad: \ldots \ldots(7.0) \quad($ (NO QUESTION))

T : Hellow--- Please---, deh...

St B $\quad: \ldots . \quad$ ((A STUDENT RAISES HAND))

T $\quad$ : Yes, Indra.. naa..muncul satu, gituu..

St B : Why hello kitty is identic with cat?

The utterance by the teacher 'Would you share your question, ladies and gentlemen?' shows the hyperbolic expression which is a repercussion from previous expression 'kok, saya yang tanya terus. (Why I keep asking)' which result in negative response from the students. Although the teacher performs polite marker 'would', 'ladies and gentlemen' in her expressions but the students feel awkward to response. This 'over-politeness' expression is negatively marked by the students by showing their silence.

\section{K. Using mockery}

Mockery was done by the teacher when she uttered 'so business in the peak, right?' and when she judged the phone left by the student with 'It doesn't look very ok, you know that. It's very old', these utterances are face-damaging to the students. As the response, the students showed negative assessment to the teacher's utterance by not giving any reply. Therefore, the situation of the students overall tends to be less active. The students only respond when the teacher asks or instructs to do presentation.

$\mathrm{T}$

St $\mathrm{T}$ THE

$\mathrm{St}$ St1

$\mathrm{T}$

St1

S2

$\mathrm{T}$

Sts

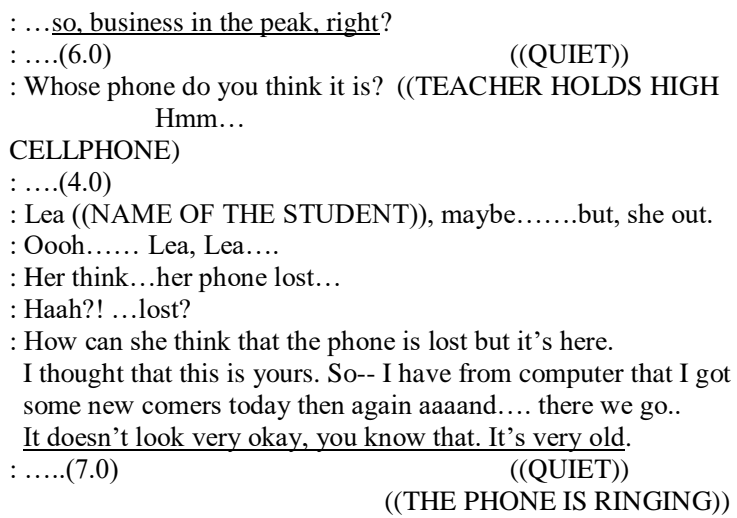


: Hallo... The phone is veryyy loud. So, to make silent everybody Where is Lea?

St1

: Go to her...her camp.

From the silence that the students showed, the mockery in the teacher's utterances has got negative response from the students. Therefore, it is regarded as impolite or inappropriate behavior according to relational work approach.

TABLE I. LINGUISTIC ASPECTS IN EFL COMMUNITY OF PRACTICE AS MARKED IN RELATIONAL WORK APPROACH OF POLITENESS

\begin{tabular}{|l|l|l|l|}
\hline \multicolumn{1}{|c|}{$\begin{array}{c}\text { Linguistic } \\
\text { Aspects }\end{array}$} & Judgment & \multicolumn{1}{|c|}{$\begin{array}{c}\text { Marking in } \\
\text { Continuum }\end{array}$} & $\begin{array}{c}\text { Relational Work } \\
\text { of Politeness }\end{array}$ \\
\hline $\begin{array}{l}\text { Addressing } \\
\text { terms }\end{array}$ & Positive & Positively marked & Polite/appropriate \\
\hline $\begin{array}{l}\text { Rising } \\
\text { intonation }\end{array}$ & Neutral & Unmarked & Non-polite/politic \\
\hline $\begin{array}{l}\text { Codeswitching/ } \\
\text { codemixing }\end{array}$ & Neutral & Unmarked & Non-polite/politic \\
\hline Using agreement & Positive & Positively marked & Polite/appropriate \\
\hline Using joke & Positive & Positively marked & Polite/appropriate \\
\hline $\begin{array}{l}\text { Using task- } \\
\text { oriented }\end{array}$ & Neutral & Unmarked & Non-polite/politic \\
\hline $\begin{array}{l}\text { Using } \\
\text { indirectness }\end{array}$ & Positive & Positively marked & Polite/appropriate \\
\hline Using metaphor & Positive & Positively marked & Polite/appropriate \\
\hline $\begin{array}{l}\text { Using non- } \\
\text { serious utterance }\end{array}$ & Negative & $\begin{array}{l}\text { Negatively } \\
\text { marked }\end{array}$ & $\begin{array}{c}\text { Over-polite/ non- } \\
\text { politic }\end{array}$ \\
\hline Using hyperbole & Negative & $\begin{array}{l}\text { Negatively } \\
\text { marked }\end{array}$ & $\begin{array}{l}\text { Over-polite/ } \\
\text { non-politic }\end{array}$ \\
\hline Using mockery & Negative & $\begin{array}{l}\text { Negatively } \\
\text { marked }\end{array}$ & $\begin{array}{r}\text { Impolite/ non- } \\
\text { politic }\end{array}$ \\
\hline
\end{tabular}

\section{CONCLUSIONS}

Employing the discursive approach in revealing politeness directs the study to establish the aspects in practice of the language use in EFL community. Linguistic aspects as captured in the naturally occurring interaction in EFL settings can be considered to be the indicator of politeness presentation in such community which English is spoken as practice. The inclusion of the linguistic aspects covers all four continuums in relational work approach. It indicates that a natural interaction cannot be regarded only as politeness, but it also can cover other kinds of behavior which termed as nonpoliteness, or over-politeness, and even impoliteness by its participants as they are found in the study.

\section{REFERENCES}

[1] G. Eelen, G. A Critique of Politeness Theories. Manchester: St. Jerome Publishing, 2001

[2] S. Mills. "Politeness and culture". Politeness in East Asia. Cambridge: Cambridge University Press pp. 20-25, 2011

[3] R. J. Watts. Politeness. Cambridge: Cambridge University Press, 2003

[4] M.A. Locher and R. J. Watts. "Politeness theory and relational works" Journal of Politeness Research. Language, Behaviour and Culture. Volume 1, Issue Page 9-33, ISSN (Online) 1613-4877, ISSN (Print) 1612-5681, 2005

[5] Terkourafi 'Beyond the micro-level in politeness research', Journal of Politeness Research, pp. 237-263, 2005

[6] J. Culpeper "Exploring the historical Chinese polite denigration/elevation phenomena" Historical (Im)politeness, Berne, Peter Lang, pp. 127-180, 2010

[7] S. Mills, "Class, gender and politeness", Multilingua-Journal of CrossCultural and Interlanguage Communication. Volume 23, Issue 1-2, Page 171-190, ISSN (Online) 1613-3684, ISSN (Print) 0167-8507, 2004

[8] A. Bouchara \& B. Corchi The role of religion in shaping politeness during greeting encounter in Arabic: A matter of conflict or understanding. Hamburg: Anchor Academic Publishing, 2016

[9] P. Brown and S.C. Levinson Politeness, Some Universals in Language Usage. New York: Cambridge University Press, 1987

[10] J. House and G. Kasper "Politeness markers in English and German" Conversational Routine, The Hague, Mouton, pp. 157-85, 1981

[11] H. Spencer-Oatey "Theories of identity and the analysis of face" Journal of Pragmatics 39.4:639-656, 2007

[12] A. J. Meier "Defining politeness: Universality in appropriateness" Language Sciences 17 (4): 345-356, 1995

[13] M.A.K. Halliday Language as a Social Semiotic: The Social Interpretation of Language and Meaning. London: Edward Arnold, 1978

[14] M. A. Locher and R. Watts "Relational work and impoliteness: Negotiating norms of linguistic behavior" In Bousfield, D and Locher, M. A. (Eds.) Impoliteness in language: Studies on its interplay with Power in Theory and Practice. Berlin: Mouton De Gruyter. 77-99, 2008

[15] J. Culpeper, Impoliteness: Using Language to Cause Offence. Cambridge: Cambridge University Press, pp. 6-7, 2011.

[16] R. Brown and A. Gilman, "The pronouns of Power and Solidarity." In: P. P. Giglioli (ed.), Language and Social Context. London: Penguin Books, 252-282, 1960

[17] G. Leech, The Pragmatics of Politeness. New York: Oxford University Press. pp. 81-83, 2014.

[18] M. Usami. Discourse Politeness in Japanese Conversation. Tokyo: Hituzi Syobo, 2002

[19] C. Claridge.Hyperbole in English. A corpus-based study of exaggeration Cambridge: Cambridge University Press, 2011. 